\title{
Performance Analysis of DC/DC Converter in MPPT Based PV System
}

\author{
Lavanya K.R ${ }^{1}$, Nayana P.Shetty ${ }^{2}$ \\ PG Scholar, Electrical and Electronics Engg., NMAM Institute of technology, Nitte, India ${ }^{1}$ \\ Associate Professor, Electrical and Electronics Engg., NMAM Institute of technology, Nitte, India ${ }^{2}$
}

\begin{abstract}
The power generation using Photovoltaic (PV) cell is the best alternative developing for fossil fuel since it does not have pollution issues. This paper focuses on performance of Cuk and Single Ended Primary Inductance Current (SEPIC) converter, used in MPPT based PV system. Perturb and Observe (P\&O) Technique used to generate duty cycle of converters. The simulation is carried out using MATLAB/Simulink and it has been observed that the SEPIC converter produces better result compared to the Cuk converter.
\end{abstract}

Keywords: Maximum Power Point Tracking (MPPT), Perturb and Observe (P\&O), Cuk Converter, SEPIC Converter.

\section{INTRODUCTION}

Solar energy has become most popular for off grid power generation. In recent days many researches showing their interest in this field to increase the efficiency and also to generate power effectively. Among all renewable energy source PV power source is one of the most promising energy source because it is reliable, recyclable, clean and inexhaustible. The PV system depends based on the solar irradiance and temperature therefore direct connection between panels to load will not possible. To increase the power generations from PV and also to reduce the effects Maximum Power Point Tracking (MPPT) methods are used.

To extract the optimum power from PV system many MPPT techniques are used. In this paper most widely used P\&O based MPPT methods are considered due to its ease of implementation. It depends on the following criterion: if a The operating voltage of the PV system is perturbed in a given direction, and if the power from the PV system increases, this means that the operating point is moving towards the MPP and, therefore, the operating voltage must be further perturbed in the same direction. Otherwise if the power from the PV system decreases the operating point is moving away from the MPP and, therefore, the operating voltage perturbed in the reverse direction.

To interface the PV panel with the load DC/DC converters are used. During atmospheric changes in the PV system DC/DC converters maintains the constant output voltage for the load condition. The converters depends upon the duty cycle which was generated from the MPPT according to the PV panel condition.

This paper evaluates the performance of PV system based on P\&O MPPT algorithm with the usage of Cuk and SEPIC Converter under changing irradiance and temperature conditions.

\section{PV PANEL MODELING}

Solar cell are mainly made up of semiconductor material which absorb the temperature and irradiance of the solar energy and converts into the dc current. Solar cells are usually connected in series and parallel to obtain the corresponding voltage and current. The series connected cells produces the large output voltage whereas the parallel connected cells produces the large output current. The modelling of the solar cell is defined by voltage current relationship of PV system as follows.

Where:

$$
I=I_{p v}-I_{s}\left(\operatorname{Exp} \frac{q\left(V+R_{s} I\right)}{N_{s} k T a}-1\right)-\frac{V+R_{s} I}{R_{p}}(1)
$$

$$
\mathrm{I}_{\mathrm{pv}}: \text { PV Current (A) }
$$

: Saturation Current (A)

: Electron Charge (1.60217*10-19 C)

: Boltzmann Constant $(1.38065 * 10-23 \mathrm{~J} / \mathrm{K})$

: Diode ideality constant

$R_{s} \quad$ : Series Resistance of cell $(\Omega)$

$R_{p} \quad$ : Parallel Resistance of cell $(\Omega)$

$\mathrm{N}_{\mathrm{s}}$ : No. of cells in series

$\mathrm{T}$ : Temperature $(\mathrm{K})$

The equivalent circuit diagram of solar cell was shown in fig.1.The output power of the solar cell depends on the solar irradiance and temperature.

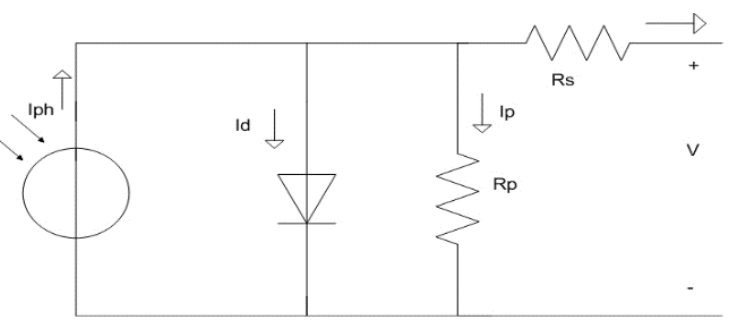

Fig. 1 Equivalent circuit of solar cell 
National Conference on Advances in Electrical Engineering

NMAM Institute of Technology, Nitte

Vol. 5, Special Issue 2, April 2017

\section{III.P\&O BASED MODELING}

P\&O based MPPT method is most commonly used MPPT algorithm. It will track the operating point of the PV system. This methodology is shown using the flowchart as in Fig.3.P\&O algorithm generates the duty cycle and it is described by the voltage and power relationship as in equation(2).

$$
\frac{d P}{d V_{p v}}(n)=\frac{P(n)-P(n-1)}{V_{p v}(n)-V_{p v}(n-1)}(2)
$$

The main drawback of using this technique are it will add oscillations to the output value. MPPT is generated by Simulink code according to the flowchartas in Fig.2.

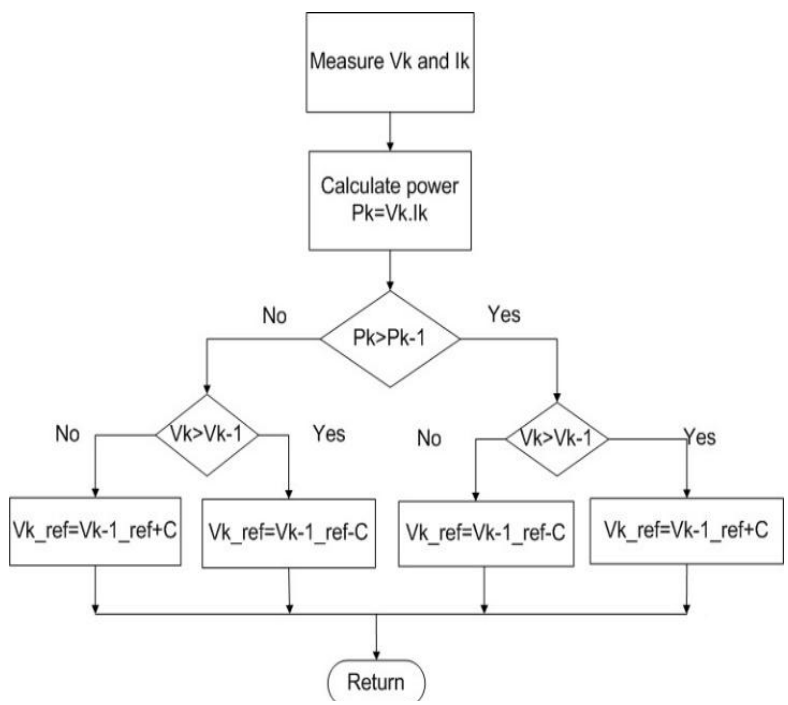

Fig.2 P\&O algorithm flowchart.

\section{IV.MODELING OF DC/DC CONVERTER}

The Cuk and SEPIC converter topology are used in this paper to compare the performance of the PV system. Both The converters are used to step up the output voltage of the PV panel.

\section{A. Modeling of Cuk Converter}

The Cuk converter is working in step up and step down principle. Depending on the input voltage output voltage can be increased or decreased and there is a polarity reversal on the output. It consists of two inductors, two capacitors, a diode, and a switch as shown in Fig. 3.The output voltage is expressed as:

$$
\mathrm{V}_{0}=-\mathrm{V}_{\mathrm{s}} \frac{\mathrm{D}}{1-\mathrm{D}}(3)
$$

Where:

$\mathrm{V}_{0}$ : Output Voltage

$\mathrm{V}_{\mathrm{s}}$ : Input Voltage

D : Duty Cycle

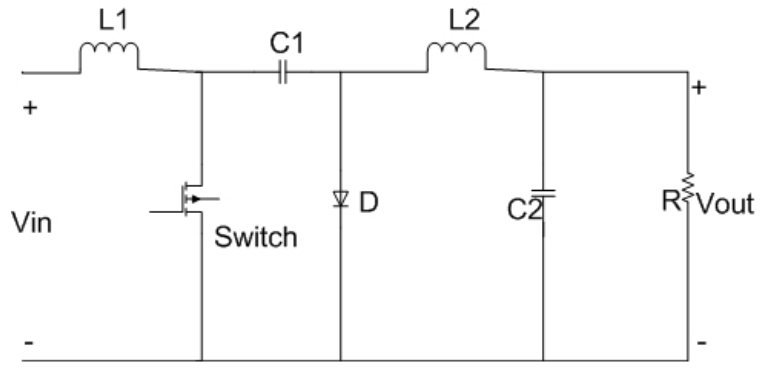

Fig. 3 Circuit diagram of a Cuk converter

B. Modeling of SEPIC Converter

SEPIC converter is similar to the Cuk converter. The SEPIC can produce an output voltage that is either greater or less than the input voltage but with no polarity reversal.It consists of two inductors, two capacitors, a diode, and a switch as shown in Fig. 4.The output voltage is expressed as:

$$
\mathrm{V}_{0}=\mathrm{V}_{\mathrm{s}} \frac{\mathrm{D}}{1-\mathrm{D}}
$$

Where:

$\mathrm{V}_{0}$ : Output Voltage

$\mathrm{V}_{\mathrm{s}}$ : Input Voltage

D : Duty Cycle

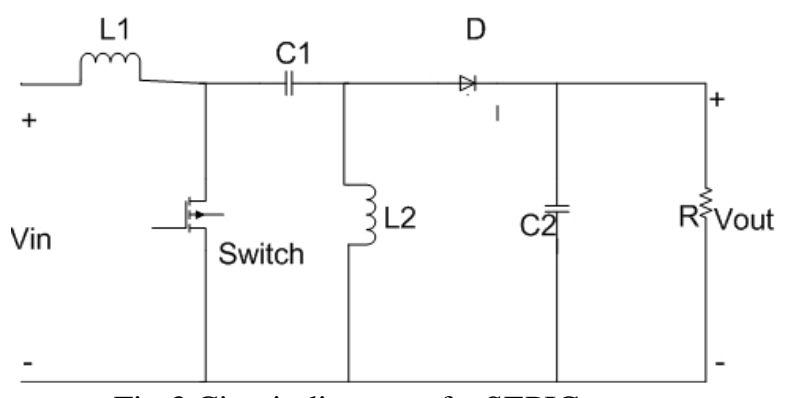

Fig.3 Circuit diagram of a SEPIC converter

\section{IMPLEMENTATION AND RESULTS}

A general overview of simulation model is shown in Fig.4. It consists of $\mathrm{PV}$ panel, DC/DC Converter, MPPT technique, $\mathrm{R}$ load.

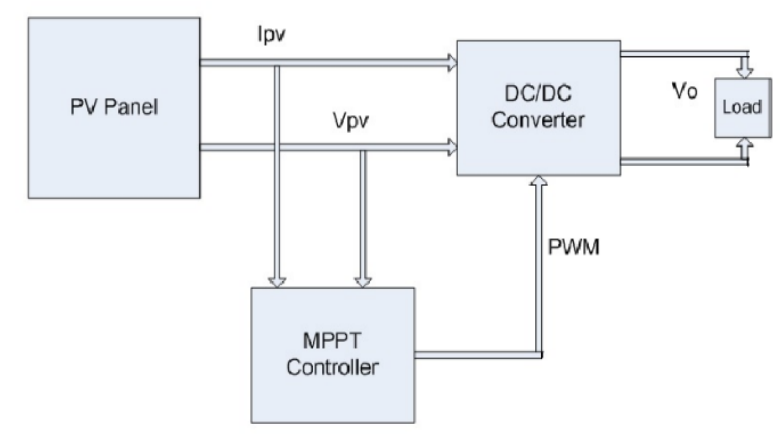

Fig.4. GENERAL OVERVIEW OF SiMULATION MODEL 
The detailed implemented Simulink model of the PV system using Cukand SEPIC Converter is shown separately in Fig $5 \& 6$. If we change the irradiance and temperature of the PV system proper tracking of MPPT is observed. The $\mathrm{P} \& \mathrm{O}$ algorithm generates the pulse according to the changes of irradiance occurred at the PV panel.

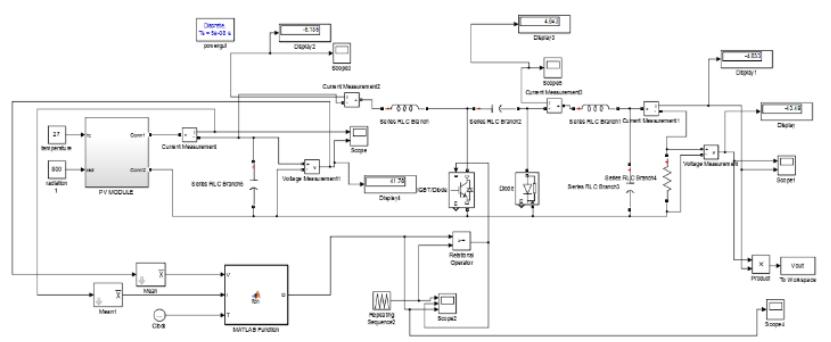

Fig.5. PV based Cuk converter simulation model

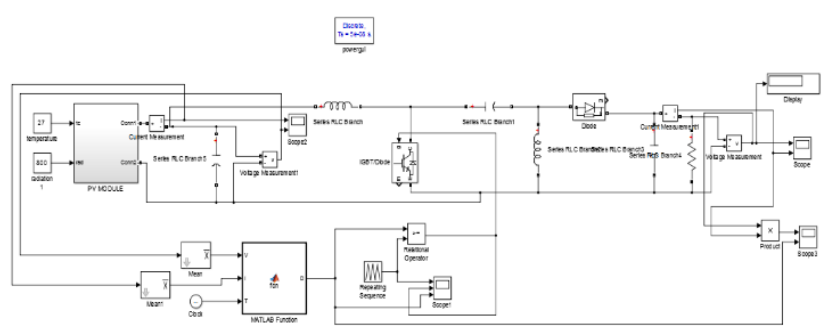

Fig.6. PV based SEPIC converter simulation model

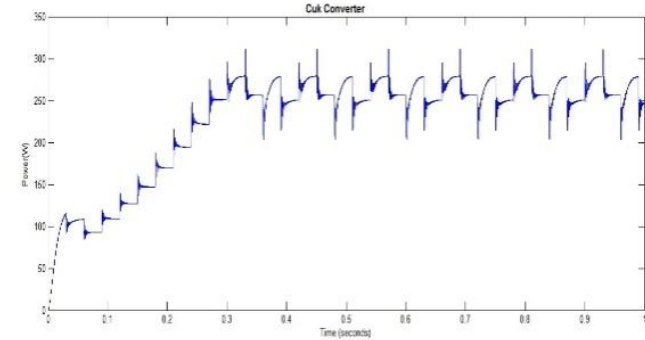

Fig.7.Output power of Cuk converter

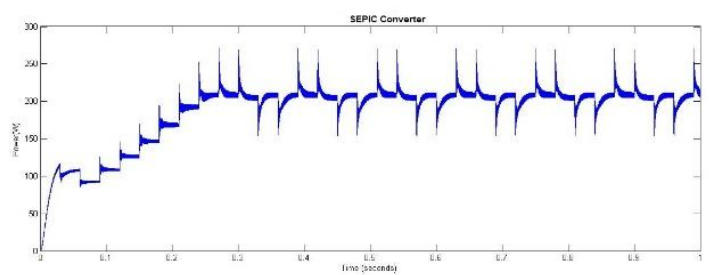

Fig.7.Output power of SEPIC converter

\section{CONCLUSION}

The simple and effective P\&O based PV system is modeled and analyzed using both Cuk and SEPIC Converters. The simulated result shows that under varying atmospheric conditions SEPIC converter is stable and gives effective output power than that of Cuk converter. The simulation is carried out using MATLAB/Simulink.

\section{ACKNOWLEDGMENT}

Authors gratefully acknowledge the support received from NMAM Institute of Technology, Nitte Education Trust and VTU, Belagavi in carrying out the research work.

\section{REFERENCES}

[1] Daniel W. Hart "Power Electronics", Valparaiso University Valparaiso, Indiana, McGraw-Hill Publication-2011.

[2] B. Subudhi, and R. Pradhan, "A Comparative Study on Maximum Power Point Tracking Techniques for Photovoltaic Power System," IEEE Trans. Sustain. Energy; vol. 4, no.1, pp. 89-98, Jan.2013.

[3] M.H. Taghvaee, M.A.M. Radzi, S.M. Moosavain, H. Hizam, and M.H. Marhaban, "A current and future study on non-isolated DCDC converters for photovoltaic applications," Renew. and Sustain. Energy, vol. 17, pp.216-227, 2013.

[4] D. Sera, R. Teodorescu, and P. Rodriguez, "PV panel model based Datasheet values", In Proc. IEEE. ISIE, pp. 2392-2398, Jun. 2007.

[5] F. Paz, and M. Ordonez, "Zero Oscillation and Irradiance Slope Tracking for Photovoltaic MPPT", IEEE Trans.Ind. Electron, vol, 61, no. 11, pp.6138-6147, Nov 2014.

[6] G. D. Cesare, D. Caputo, and A.Nascetti, "Maximum power point Tracker for photovoltaic systems with resistive like load," Solar Energy, vol. 80, no. 8, pp. 982-988, 2006. 